\title{
Erratum: So, what's your story? - The role of storytelling in nurturing inclusive congregational identity
}

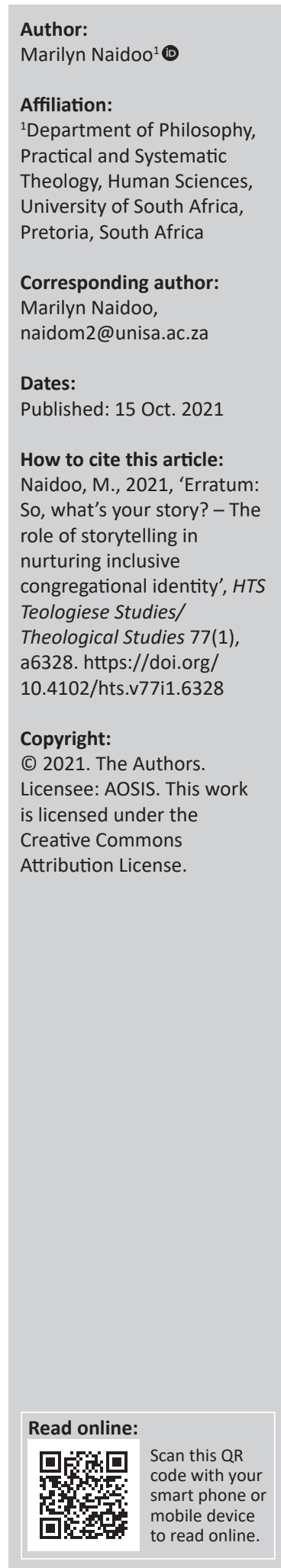

In the version of the article initially published, Naidoo, M., 2019, 'So, what's your story? - The role of storytelling in nurturing inclusive congregational identity', HTS Teologiese Studies/Theological Studies 75(4), a5448. https: / doi.org/10.4102/hts.v75i4.5448, on page 6, in the 'Ethical consideration' statement, the ethical clearance registration number was incorrectly written as '2017 CAS 030'. The correct number is ' 2017 CHS 030'.

This correction does not alter the study's findings of significance or overall interpretation of the study's results. The publisher apologises for any inconvenience caused. 


\section{So, what's your story? - The role of storytelling in nurturing inclusive congregational identity}

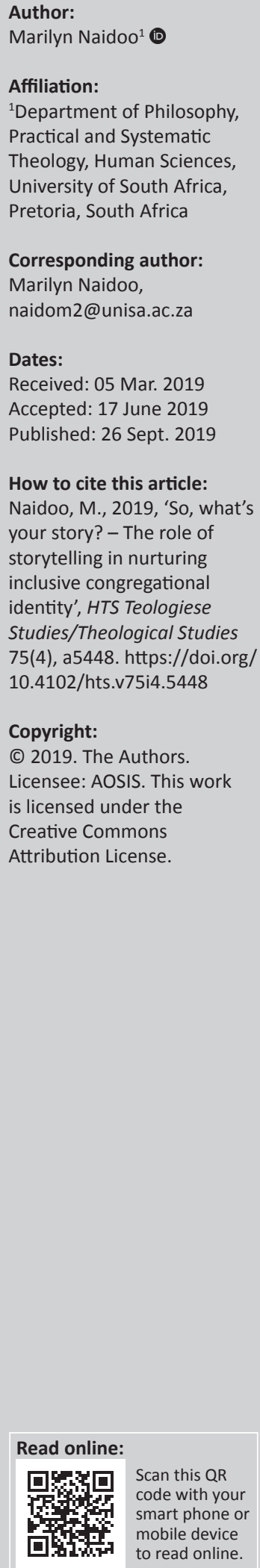

South African churches are struggling to form cohesive communities and strategies are needed to bring people together. Because of a deficiency in trust, people are reluctant to get to know each other, impacting on the quality of relationships and a positive sense of belonging and community. Congregations need to find ways to nurture an inclusive identity instead of the current norm of all-white or all-black churches, which can be perceived as being inaccessible or exclusive. Innovative strategies like storytelling can unlock the power to understand each other breaking down prejudice, racism and xenophobia. Because intercultural socialisation is found wanting in congregations, sharing different perspectives and experiences can deepen engagements overcoming superficial interactions. This article expands on how storytelling can be used to facilitate an inclusive and intercultural congregational identity through identity formation, liberative practices of reconciliation, community building and as an educational resource.

Keywords: Storytelling; Multiculturalism; Narrative pedagogy; Congregational identity; Reconciliation; change agent.

\section{Background}

The church is shaped by how local congregations attempt to 'give expression to the gospel and received ecclesial traditions in ways appropriate to their local social and cultural contexts' (Carroll 2000:2). Reconciliation in churches is a public concern in a society such as South Africa (Naidoo 2017:5). This is in line with the 'church health' literature that builds on wide-ranging theological assumptions of the church as having potential for being an instrument for moral and social good (Ammerman 1997; Carroll 2000).

Given the role of the church in supporting democracy, one would have expected that the church would have played a leading role in the post-conflict transition and found new ways of 'being church'. This would be an example of 'local ecclesiology' (Schreiter 1985) where local congregations are appropriate to the cultural and social context of society, rather than simply an evangelical focus of numerical growth. However, as Van der Merwe states (2003:269), 'for the church to seriously consider itself as an agent of reconciliation, it would have to firstly look at how these internal divisions can be dealt with,' to support the establishment of just and humane social structures.

Congregations are subcultures of our larger divided society. Thus, social divisions within churches are a reality; mistrust among members or divisions between different congregations with racial and cultural tensions. 'Race, ethnicity and national identity are unfinished ecclesial business for churches in South Africa' (Van der Borght 2009:5), which makes churches excellent laboratories for reconciliation. Racial micro-aggressions in congregations can be common place, typically unconsciousness and subtle. We are daily reminded of the intolerance towards others; we know of the growing trend of 'white flight' when congregations embrace an African worship style. The establish congregational culture protects its identity in both overt and subtle ways amid social change. Brunsdon (2017:1) declares that 'the lack of a consolidated identity has become one of the most worrying South African realities'

Much has been written about the Christian ideals of forgiveness and reconciliation (Amstutz 2005; Tutu 1994, 2000; Villa-Vicencio 1997), with the aim of shaping an inclusive South African identity. The newer phenomenon of multicultural congregations in our context highlights a newer type of community which is not mainstreamed but has potential towards social reconciliation.

Note: The Church in need of Change (agency), sub-edited by Erna Oliver (University of South Africa). 
Bush states that 'multicultural churches have great relevance for societies in transition' (2016:62). According to Gordon Allport's contact theory (1954), intergroup relations improve with contact. Two essential factors are needed: exposure to other cultures and worldviews and a capacity for empathy and mutual perspective-taking. When members in a congregation share a common history or common experiences, the fact of this sharing can shape a common identity (Ammerman et al. 1998:3436). But this is more likely if the congregation can nurture an inclusive congregational identity which entails more than bringing a mix group together, but is dependent on the quality of the relational and social connections that members nurture across cultural difference (Christerson, Edwards \& Emerson 2005:62; Garces-Foley 2007). This type of identity is about the socially constructed sense of 'we' that bonds members to a group and to one another. It is also 'more than just tolerance or assimilation into the dominant culture' (Bush 2016:54). Nevertheless, counteracting forces of a segregated society impact the integration of church communities. We know that the gospel is not captive to any one cultural style, aesthetic, generation, social class, cultural or racial group. At the same time, however, the gospel comes alive for people most frequently when it is expressed in the clarity of their culture. We also have to acknowledge that we live in a society where suspicion, fear and racism shape us every day. As individuals we are thoroughly enculturated and shaped by social and cultural influences. Because of the pressures for social distance, establishing relational bonds can be a challenge. The sociologist Ammerman (1997:45) reminds us that 'racially diverse congregations do not develop automatically, even in the most culturally mixed and integrated communities.' These congregations highlight that without spiritual intervention to transform people personally and as a group, behaviour will be limited by cultural and human habits.

In our context, mono-cultural congregations remain the norm, which could 'serve as enclaves for those from the same cultural group' (Cilliers \& Nell 2011:5) with a culture of privacy - a reluctance to open sharing and self-disclosure even in smaller group settings. Research has shown that intention to include others is sacrificed over some congregations' desire for their own internal solidarity and belonging (Emerson \& Smith 2000:144). Status quo practices prevail entrenching the exclusion of others; thus, to overcome embedded patterns of behaviour requires intentionality within the institutional culture.

Bringing together very different cultures involves a shift in values and worldview. It involves 'cultivating a shared, collective identity that transcends participants' personal ethnic identities' (Marti 2005:6). Small groups (Wuthnow 1994) within the church have been a proven strategy for encouraging multiculturalism, where individuals across races and culture can gather. Within these groups, another useful strategy is storytelling. It is powerful because it touches people at a very personal level. Because telling stories is so basic to human nature, people tend to forget its importance:

Stories give pleasure because they're free of the worry about being correct in every detail and provable. They allow us to consider insolvable issues and deepen rather than solidify our reflection. (Moore 2003:67)

Storytelling is a universal human activity and can be a powerful tool for developing multiculturalism and reconciliation. Telling one's story, revealing one's pain, expectation and confessing regret is a primary practice of reconciliation used by individuals and groups. This is mostly closely related to penitence, a type of liberating and transforming testimony (Lefebvre 2013:15). According to Tutu (2000) at the TRC, healing occurred through the act of storytelling:

We allowed those who came to testify mainly to tell their story in their own words ... (and discovered that) there were in fact different orders of truth ... There was ... forensic factual truth ... and there was social truth, the truth of experience that is established through interaction, discussion and debate. The personal truth ... was a healing truth ... many bore witness to the fact that coming to the Commission had a marked therapeutic effect on them. (p. 62)

Storytelling encourages social interaction across difference and can ultimately help churches deepen their reconciliation potential, playing a crucial role in building social capital. Congregations need these types of practical actions, safe spaces and the opportunity to hear each other's stories that could 'shatter stereotypes and beliefs that have acted as a dividing wall' (Wielenga 2013:3). Yet, congregations need to be intentional in this regard so that they move beyond a churchy superficialness or Christian piety that assumes all is well. This article will look at the strategy of storytelling or narrative (used interchangeably in the literature), which is a methodology that can act as a change agent to help see the 'other' as human being. I will describe the characteristics and process of storytelling and mention its role in forming identity, creating liberative practices of reconciliation, serving in community building and as an educational resource.

\section{Participatory research}

Because storytelling is a process of deepening our relationships with others, I wanted to understand the potential of this resource. As part of a research project on social cohesion I was part of an Anglican congregation in Johannesburg. This is a vibrant parish of about 300 members that describes itself as an eclectic, rainbow mix of people from various backgrounds. They took part in a six-week Lenten programme of storytelling called 'What's your story?' which I attended. The programme was facilitated by the Heartlines Foundation, an NGO focused on values promotion and building social cohesion working in various sectors of society. In the programme personal storytelling was used as a non-threatening foundation; a way to start breaking down the suspicions and prejudices that divide church members, working towards social reconciliation. The basic mode of 
operation was asking, listening and telling personal stories. In the introductory session, the programme began with understanding the aim of the programme and the benefit for the congregation. The overall goal of this programme was viewed as 'building understanding, greater cohesion and, eventually trust and reconciliation through the sharing of our stories' (Moloi 2016:14). About 50 church members were in attendance regularly each week for 6 weeks of different age, culture and race backgrounds. We started the first session by watching the South African movie 'Beyond the River' which is a true story about a white and a black man whose quest was to complete the Dusi river canoe marathon. In the movie, this interaction connected them during physical training and on an emotional level beyond the river. After the movie, we discussed the developing relationship between the characters and how we, as ordinary South Africans, related to the characters, also needed to go through the same process of 'seeing' and understanding other people. Each week thereafter, we would watch a documentary style video of inspiring individuals telling their personal stories, followed by the small group work of storytelling.

In my small group there were four other participants; three females and one male made up of different races and cultural groups. We met each week, sharing our individual story in detail, of key moments of change and transformation. It was revealing and interesting to hear how and what stories were presented and how vulnerable members became. In our small group, Doris spoke of her faith and pivotal memories of not being 'seen' in a family that did not have all the means in the dusty townships of Soweto. Esther mentioned her transition from Zimbabwe to South Africa and her time in secondary schools, and as a teenager the challenge of fitting in and not being able to relate to other Black South Africans. Joshua spoke mostly of one incident of crime in his final year of high school that made him realise that he could have wasted his life in prison. For him it was an affirmation of God's direction in his life, even to a call in Christian ministry. Listening to these stories was humbling and made us relate to the pain in another's life. It awoken deep emotions and made us understand the other person in a far more compassionate way. Through storytelling, we felt we were individually heard, recognised and acknowledged by others in the group. These stories made us 'see' the other again, thereby breaking down stereotypes. At the end of the programme our group committed to continue meeting and deepen the relationship that was started at the church. Over time, unfortunately, the established bonds formed were not sustained and the social interaction died down. This has been the reality with other groups in the church as well.

For this method to be used effectively, it needs to be support by other programmes and not viewed as an isolated event in an already overcrowded church programme. It must become a long-term encounter that can lead to engaging conversations about culture, stereotypes, identity and working towards togetherness in our nation. For this to happen, leadership is critical and various innovative practices are required to embody the vision of multiculturalism and align it throughout the life of the community in culturally appropriate ways. At the same time, through my ongoing research I am aware of other churches that have used storytelling successfully for a few years now, evident in thriving inter-cultural congregations, like the church Every Nation, in Rosebank, Johannesburg. As they state that as a congregation there is a 'letting go of tribal comfort zones and ideological bondages of the past to embrace the new thing that God is doing in the nation' (Neville 2016:11).

Stories can truly reconcile a nation, and it has been used by various churches and Christian groups to promote diversity, reconciliation and build stronger relationship; a few examples include (Moloi 2016:15):

- The National Initiative for Reformation of South Africa hosted by African Enterprise in the early 1990s brought together Christian leaders from different denominations.

- YFC diversity youth camps in the 1980s and 1990s saw young people of all race groups interact with each other over a number of days.

\section{Why storytelling?}

Storytelling is basic to being human because in telling our stories we bring meaning to our lives that is not a luxury but fundamental to the task of being human. Widdershoven (1997:8) writes, 'Stories make explicit the meaning that is implicit in life as it is lived. Stories are interpretations of life in which the meaning of life is spelled out'. Stories make the hidden seen, the unformed formed and the confusing clear.

Life is a constant dialogue with stories from other people and of us trying to process the experiences of life.

We carry part of our personal and collective past into the present with each act of our lives. So, our stories are embedded in the stories of others and in the broader social, cultural and political narratives (Polkinghorne 1996). Shared expectations of what it means to be a citizen, for example, is communicated, so stories transfer wider social meanings (Bruner 1990). We share events and situations that are drawn from a universal archetype that is common to all other human beings. When we tell stories, 'we invite people to enter a world that may be different from their own, but remarkably similar in many ways' (Bruner 1990:43).

Rosenwald and Ochberg state that 'stories reflect their interaction with the world and their attempts to create a unique position for themselves within the complexities of multiple layers of reality' (1992:9).

We also tell the story from our experience to increase the working knowledge of self through the process of reflecting and placing feelings and experiences into oral expression. Typically, stories have a plot, characters, scenes, locations and resolutions that keep the story on course. Embedded in the story are the actions, motivations, cultural worlds and assumptions of major characters. Story is connected with human memory and it is the means to use earlier experiences 
to solve problems in the present. Atkinson states that when we recall different dimensions of the story, 'they give us hooks on which to hang new moments and frames within which to make sense of some new experience' (1998:6). To make sense of the story, we tie events together and plot their sequences across time from beginning, middle, to end. Usually, the basic sequence is conflict followed by resolution which is a way that stories continually remind us that difficulties can be overcome (Shaw 1999). In unravelling our story important personal truths are shared, and we thereby create important connections to others who then take part in that exchange. It has been said that 'stories are the state-ofthe-heart-technology' as they create emotional connections.

The Christian faith also is a great narrative of redemption and salvation. The Old Testament is filled with stories that illustrate who the God of the Israelites was and that indicate how their God could be differentiated from the other gods of the time. Oral tradition was key in communicating concepts of God from generation to generation (Pr 22:6). In the New Testament, we find that Jesus often used parables or moral stories as a way of teaching theological concepts and principles to his listeners, like the well-known example of the parable of the prodigal son (Lk 15). Stories become easy to understand ways to explain complex theological truths and are used throughout Christian education to establish and maintain faith, as Moore reminds us 'it is in our stories that doctrinal theology demonstrates its value' (1988:250). Stories change how we understand key truths of the faith and move us to transformative practice in our broken society.

Our modern, highly differentiated and individualistic society also makes it difficult to remember our past, and, worse, substitutes ideology for deep narratives. Stahl and Stenmark (2004) state that:

$[N]$ arrative discourse has been replaced by scientific-technical calculation and with this we have lost much possibility for moral unity in our individual lives and historical unity in our moral traditions. As moral meanings become fragmented, society becomes unsusceptible to emplotment. (p. 60)

Traditionally, understanding theology has been an academic and cerebral exercise concerned with rational analysis, dissection and systematisation. Even George Lindbeck (2002:208) suggests that the introduction and proliferation of historical-critical interpretative methods have caused us to lose the narrative meaning of the scriptures. We experience a loss of community, a sense of alienation and meaninglessness, loss of agency, and inability to commit to a course of action and, most disastrously, the inability to tell the truth about what we are up to. The modern 'crisis of meaning' is a crisis of narrative. Because we cannot process the complexity of the world we live in, we look for generalisations that can be found in stories. Simmons states that we are disconnected by an ocean of data and choices that is overwhelming, 'stories interpret raw facts and proofs to create reality. Change the story and you change the meaning of the facts' (2007:3). The only way out is to regain the ability to understand narratives in their deep sense, to re-learn how to be transformed by stories and how to transform the world through our stories. Alasdair MacIntrye states that 'hearing and the telling of stories is a crucial moral resource ... in a world that seems increasingly incoherent and despairing' (1981:6).

\section{Developing inclusive congregational identity}

In our racialised South African society, working towards an inclusive identity within congregations involves developing a new hybrid, a 'mestizaje national culture' (Warner 1996) in which the cultural complexity of a nation is represented. Yancey (2003) states that this type of identity in congregations has the worldview of 'theological oneness' where reconciliation is the centrepiece of faith. Ganiel, who has conducted multicultural congregational research in South Africa, states that these types of churches 'recognizes, embraces, utilizes and celebrates the racial, cultural, generational, gender, and other diversity represented in the community and the church' (2007:8). Matters of boundary crossing, encountering cultural difference and dealing with issues of inclusion and difference are addressed. Here:

[C]ultural differences are neither swept away nor diversity promoted over similarity; rather, faith serves as a bridge to make the rich mixture of cultures in society a part of the congregation's consciousness. (Bush 2016:22)

However, for an inclusive identity to become a reality there must be strong leadership, which is the sine qua non for developing innovative congregations. Providing leadership involves providing safe spaces to have discussions about the relationship between faith, culture and race and the congregation's current practice. It involves envisioning what a congregation might become and seeing the connections between present reality and a vision for the future. To sustain inclusiveness as a core belief, congregational leadership needs to make the emphasis at every turn in teaching and practices so that it becomes a lived reality for all members.

Actions needs to be intentional, experiential and relational through programming and 'relational connections that promote congregational adaptability' (Ammerman et al. 1998:67).

Storytelling, because of its socially constructed nature, is useful to teach us to listen again, to see the human behind the story instead of the stereotype. It can nurture positive relationships in community and empathy. It is especially helpful in developing congregational inclusivity through the three areas of identity formation, liberative practices and as an educational task.

\section{Stories as identity formation}

Stories foster an unfolding of self. In storytelling, the story is told the way the person chooses to tell it and therefore it can be empowering in terms of forming identity. Stories help to understand how the self evolves over time providing integration and a better understanding of feelings, emotions, 
experiences and what they mean. This is a way of organising meaning and verifying identity (Ricoeur 1984). According to narrative identity theory, our identity is made up of the stories we 'remember and choose to tell about ourselves' (Byrd 2011:250). It also suggests that 'we are the stories that we tell about ourselves' (Kenyon 1996:26), which shape the way we view the world, the morals we adopt and how we see our place in the world. From this stance, 'stories can be considered as carrying themes, or "selves" that make up a larger, overarching self-narrative' (Bruner 1990:34).

Narrative pedagogy is essentially learning as an identity project where person narratives can be used so that individuals come to a deep sense of personhood, find opportunities to deepen relations with others, is a springboard for ethical actions and new insights all within the individual's social, cultural and political context. This process results in 'fuller or richer stories of personhood in relation to what is taught' (Miller 2003:64). This is a way of 'opening up people's minds to a complete reversal of their story' (Bruner 1990) to a new way of self-understanding. In trying to understand people, it is important to allow people speak for themselves, to allow their first interpretation of the story, their personal construction of reality. A consciousness (Freire 2000) about ourselves and our situation allows us to be creative subjects in bringing about change. When we are aware of our stories and habits, we can build on this and attend to weakness as an on-going analysis and self-reflection. In this way, identity is then not a once-off label, but is fluid, influenced and shaped by stories over time.

Within a congregation there are a range of roles and positions that exist. Forming identity with others involves understanding commonalities and difference and how to deal with dominant constructs in the community (Nauta 2007:42). As people tell their stories, it can illustrate how identity is developed and changing through the social and spiritual context of the community. The power of story in identity formation can be death-dealing or life-giving role, as Rogers notes (2011):

The self is a story - each of us, in essence, the central protagonist in the novel of our life ... This narrative sense of identity is informed, sometimes for good, sometimes for ill, by the narratives of one's community. Destructive narratives erode a vital sense of self, while life-giving narratives can heal and restore. (p. 56)

Identity is formed by the community. Stories are the potential glue for community because individual stories fit into the bigger story. Narratives are important to develop a common story in the life of the church. In our society and in congregations we value individualism, but this is an oxymoron as we need other people for meaningful relationships. The critical task for congregations is the development of authentic community.

\section{Stories as liberating practice}

Storytelling has the potential to change history when people reflect critically on their own stories while engaging others.
Espinoza reminds us that storytelling has the ability to free people from 'oppressive and sinful narratives and mindsets and help them to take action to transform their thoughts, behaviors, and contexts' (2013:433).

Social class together with ethic, cultural and racial differences play important roles in influencing how people hear, understand and interpret the gospel - how they worship; what hymns and music they appreciate and what needs they bring to congregational involvement. Knowing one's congregation; how similar or different members are in lifestyles and needs, is crucial for current and future church forms and practices (Carroll 2000:90). The South African Reconciliation Barometer, a national survey measuring reconciliation, states that 'progress towards reconciliation in South Africa cannot take place without opportunities for, and willingness to engage in, meaningful connection and interaction between different race groups' (2017:8).

In congregations, when people do not have the space to dialogue about identity and social relations, fear and stereotyping remains. John Lederach (1997:26) contends 'that we do not achieve reconciliation by finding creative ways to avoid one another but by intentionally engaging each other as humans-in-relationship'. With the internalisation of apartheid stereotypes many years after democracy, there remains a need for a resocialisation towards seeing all people as having equal value. Balcomb (2000:53) asserts that where stories have been harmful, 'we need to consciously choose to have our stories shattered in order to be able to develop new stories'. A shift can result within individuals when they critique their own story and reconsider their position in the society, which is imperative for emancipation. This shattering brings into question the ingrained ideas we have about others and allows new stories to emerge, thereby accommodating more inclusive and less destructive actions. This type of individual agency in self-reflection depends on new social practices that should be embedded in congregations. Freire (2000:62) refers to this type of agency as 'culture-creators' persons who shape their own culture and context. To do this, skills are needed for communication that extends beyond an intellectual understanding to the skill of critical humility and compassionate listening. This way of being is similar to Freire's (2000) idea of the human as 'being unfinished.' This is about having an awareness that we have more to learn our own 'unfinishedness' and an openness to consider other possibilities. It includes listening and questioning, a 'hospitality to the differences of others instead of reducing everything and everyone to the sameness of a predetermined mode' (Garrison 2010:2764).

Reconciliation firstly involves being reconciled with God out of which the result is the 'restoration of relationships and the recovery of the dignity and humanity of both the victim and perpetrator' (Hay 1999:12). Christians in congregations should realise that sustaining these new relationships is part of prophetic calling and not just the focus of personal 
salvation. In addition, when a strong sense of community (McMillan \& Chavis 1986:10) is realised expressed in the interactions between members, this results in church growth (McGaw 1980:21). This is because belonging is fundamental in generating and maintaining commitment.

\section{Stories having educational potential}

Storytelling can be viewed as educational because when we tell and re-tell our stories, this allows for engagement with the Christian story to shape our personal story. Narrative pedagogy is useful for transmitting knowledge via biblical narratives about the Christian tradition, as well as useful in religious identity development and in spiritual growth. In churches, there are various modes of engagement in sermons, Bible study discussions or intergenerational storytelling. However, stories need not be communicated in verbal language only; narrative pedagogy is an 'educational method that intentionally uses the narrative arts of storytelling, drama, and creative writing to nurture theological reflection, spiritual growth, and social empowerment' (Rogers 2011:15). McAllister et al. (2009) define the educational and liberating ability of narrative pedagogy:

Through narrative, one can appreciate embodied knowing: what an experience feels like in a subjective and close way, rather than what it looks like in an objective and dispassionate way; one can learn facts as well as social impacts; one can be moved towards action rather than simply understanding. (p. 157)

The use of stories and metaphor in theology offers the possibility of greater integration - of body and spirit, academic theology and lived experience - in a way that our usual disembodied theology does not (Miller 2003:62). To return to wholeness, Christian theology will have to recapture the essential nature of Christianity as story - the gospel story that still lives and creates its own hearers and tellers. This type of pedagogy is different from the transmission mode or banking education (Freire 2000). As Freire reminds us that 'education is never neutral; education always endorses the status quo or contributes to the revolution of the world' (2000:67). Instead of the leader inviting members into a story, narrative pedagogy welcomes all members of the group to tell stories. Here there is no traditional hierarchy between the teacher and the group and everyone is a source of knowledge that is appropriate to congregational learning. Rossiter and Clark (2007) posit that:

the informed and mindful use of narratives in education stimulates the capacity to receive among learners and educators alike. Just as a loving or caring act is completed only when it is received, so a story must be received for it to have meaning (p. 10)

\section{Conclusion}

This article has emphasised how storytelling can deepen faith and be a way to facilitate closer social interactions in congregations. This is because stories can evoke experiences in our lives and link our humanity to the humanity of others. Within our context, to create an inclusive congregational identity, we need strategies to start the process of personal healing and reconciliation. By engaging stories critically, it can liberate people from oppressive narratives to new ways of seeing and being.

Space must also be created to interrogate visions of unity in creating community. This concept of unity, which no longer means a state of sameness, is complicated. It requires a process of constantly working towards a united front. There must be resources, programmes and practices that embody that united vision, so that an initiative like 'What's your story?' is not perceived as ad hoc and therefore optional but becomes intentional practices for moving people from the periphery to the core. It involves the difficult work of exploring, teaching and demonstrating what it means to live one's life reflectively guided by the Christian story.

\section{Acknowledgement Competing interest}

The author has declared that no competing interests exist.

\section{Author contributions}

I declare that I am the sole author of this research article.

\section{Ethical consideration}

This article followed all ethical standards for carrying out research with ethical clearance registration 2017 CAS 030.

\section{Funding}

The author gratefully acknowledges the National Research Foundation for providing a research grant (No. 105930) for conducting this study.

\section{Data availability statement}

The data that support the findings of this study are available from the corresponding author.

\section{Disclaimer}

The views and opinions expressed in this article are those of the authors and do not necessarily reflect the official policy or position of any affiliated agency of the authors.

\section{References}

Allport, G., 1954, The nature of prejudice, Addison-Wesley, Reading, MA.

Ammerman, N., 1997, Congregation and community, Rutgers University Press, New Brunswick.

Ammerman, N.T., Carroll, J.W., Dudley, C.S. \& McKinney, W. (eds.), 1998, Studying congregations. A new handbook, Abingdon Press, Nashville, TN.

Amstutz, M., 2005, The healing of nations: The promise and limits of political forgiveness, Rowman \& Littlefield, Lanham, MD.

Atkinson, R., 1998, The life story interview, Sage, London.

Balcomb, A., 2000, 'The power of narrative: Constituting reality through storytelling', in P. Denis (ed.), Orality, memory and the past: Listening to the voices of Black Clergy under colonialism and apartheid, pp. 51-61, Cluster Publications, Pietermaritzburg.

Bruner, J., 1990, Acts of meaning, Harvard University Press, Cambridge, MA. 
Brunsdon, A.R., 2017, '\#Misconstrued IdentitiesMustFall collective: Identity formation in the current South African context: A practical theological perspective', HTS Theological Studies 73(2), 1-7. https://doi.org/10.4102/hts. v73i2.3822

Byrd, M., 2011, 'Narrative discipleship: Guiding emerging adults to "connect the dots" of life and faith', Christian Education Journal, Series 3 8(2), 244-262. https://doi. org/10.1177/073989131100800202

Bush, J.E., 2016, Practical theology in church and society, Cascade Books, Eugene, OR.

Carroll, J.W., 2000, Mainline to the future: Congregations for the 21st century, Westminster John Knox Press, Louisville, KY.

Christerson, B., Edwards, K.L. \& Emerson, M.O., 2005, Against all odds: The struggle for racial integration in religious organizations, New York University Press, New York.

Cilliers, J. \& Nell, I.A., 2011, "Within the enclave". Profiling South African social and religious developments since 1994', Verbum et Ecclesia 32(1), 4-6. https://doi. org/10.4102/ve.v32i1.552

Emerson, M.O. \& Smith, C., 2000, Divided by faith: Evangelical religion and the problem of race in America, Oxford University Press, New York.

Espinoza, B.D., 2013, 'The Christian story and our stories: Narrative pedagogy in congregational life', Christian Education Journal 10(2), 432-443. https://doi. org/10.1177/073989131301000213

Freire, P., 2000, Pedagogy of the oppressed, Continuum, New York.

Ganiel, G., 2007, 'Religion and transformation in South Africa? Institutional and discursive change in a charismatic congregation', Transformation: Critical Perspectives on Southern Africa 63, 1-22. https://doi.org/10.1353/trn.2007.0018

Garces-Foley, K., 2007, Crossing the ethnic divide: The multiethnic church on a mission, Oxford University Press, New York.

Garrison, J., 2010, 'Compassionate, spiritual and creative listening in teaching and learning', Teachers College Record 112(11), 2763-2776.

Hay, M., 1999, Ukubuyisana: Reconciliation in South Africa, Cluster Publications, Pietermaritzburg.

Kenyon, G., 1996, 'The meaning/value of storytelling', in J.E. Birren, G.M. Kenyon, J.-E Ruth, J.J.F. Schroots \& T. Svensson (eds.), Aging and biography: Explorations in adult development, pp. 21-38, Springer Publishing Company, New York.

Lederach, J.P., 1997, Building peace, United Institute of Peace, Washington, DC.

Lefebvre, S., 2013, 'Reconciliation through creativity: Storytelling and music', in J. Haers, F. Wilfred, K. Justaert \& Y. De Maeseneer (eds.), Reconciliation: Empowering grace, pp. 13-23, SCM Press, London.

Lindbeck, G.A., 2002, 'Scripture, consensus and community', in J.J. Buckley (ed.), The church in a postliberal age, pp. 201-212, Eerdmans, Grand Rapids, MI.

Marti, G., 2005, A mosaic of believers: Diversity and innovation in a multiethnic church, Indiana University Press, Bloomington, IN.

McAllister, M., John, T., Gray, M., Williams, L., Barnes, M. \& Allan, J., 2009, 'Adopting narrative pedagogy to improve the student learning experience in a regional Australian university', Contemporary Nurse 32(1-2), 156-165. https://doi.org/ 10.5172/conu.32.1-2.156

MacIntrye, A., 1981, After virtue, 2nd edn., Notre Dame University Press, Notre Dame, IN.

McGaw, D.B., 1980, 'Meaning and belonging in a charismatic congregation: An investigation into sources of neo-Pentecostal success', Review of Religious Research 21(3), 284-301. https://doi.org/10.2307/3509809

McMillan, D.W. \& Chavis, D.M., 1986, 'Sense of Community: A Definition and Theory', Journal of Community Psychology 14(1), 6-19. https://doi.org/10.1002/15206629(198601)14:1\%3C6::AID-JCOP2290140103\%3E3.0.CO;2-1

Miller, M., 2003, Experiential storytelling: (Re)discovering narrative to communicate God's message, Zondervan, El Cajon, CA.

Moloi, N. (ed.), 2016, What's your story: An initiative of heartlines, Supreme Printers, Johannesburg.
Moore, M.E., 1988, 'Narrative teaching: An organic methodology', Process Studies 17(4), 248-261. https://doi.org/10.5840/process198817415

Moore, T., 2003, The soul's religion: Cultivating a profoundly spiritual way of life, Perennial, New York.

Naidoo, M., 2017, 'The potential of multicultural congregations in supporting social reconciliation', HTS Theological Studies 73(4), 1-8. https://doi.org/10.4102/hts. v73i4.4622

Nauta, R., 2007, 'People make the place: Religious leadership and the identity of the local congregation', Pastoral Psychology 56(1), 45-52. https://doi.org/10.1007/ s11089-007-0098-6

Neville, N., 2016, Better together: Crossing the divide in South Africa, Lionheart, Johannesburg.

Polkinghorne, D.E., 1996, 'Explorations of narrative identity', Psychological Inquiry 7(4), 363. https://doi.org/10.1207/s15327965pli0704_13

Ricoeur, P., 1984, Time and narrative. University of Chicago Press, Chicago, IL.

Rogers, F., 2011, Finding God in the graffti: Engaging teenagers through stories, Pilgrim Press, Cleveland, $\mathrm{OH}$.

Rosenwald, G. \& Ochberg, R.L., 1992, Storied lives, Yale University Press, New Haven, CT.

Rossiter, M. \& Clark, M.C., 2007, Narrative and the practice of adult education, Krieger, Malabar, FL.

Schreiter, R.J., 1985, Constructing local theologies, Orbis Books, Maryknoll, NY.

Shaw, S.M., 1999, Storytelling in religious education, Religious Education Press, Birmingham, AL.

Simmons, A., 2007, Whoever tells the best story wins: How to use your own stories to communicate with power and impact, vol. 5, pp. 3-4, American Management Association, New York.

Stahl, W.A. \& Stenmark, L.L., 2004, 'Stories that matter: A narrative approach to implicit religion', Implicit Religion 7(3), 256-275. https://doi.org/10.1558/imre. 7.3.256.66314

The South African Reconciliation Barometer, 2017, The Institute for Justice and Reconciliation, viewed 11 January 2019, from http://www.ijr.org.za/home/wpcontent/uploads/2017/12/IJR-Barometer-Report-2017-web.pdf.

Tutu, D., 1994, The rainbow people of God, Doubleday, New York.

Tutu, D., 2000, No future without forgiveness, Random House, New York.

Van der Borght, E.A.J.G., 2009, Sunday morning - The most segregated hour: On racial reconciliation as unfinished business for theology in South Africa and beyond, VU University Amsterdam, Amsterdam.

Van der Merwe, H., 2003, 'The role of the church in promoting reconciliation in post TRC South Africa', in A.R. Chapman \& B. Spong (eds.), Religion and reconciliation in South Africa, pp. 281-296, Templeton Foundation Press, Philadelphia, PA.

Villa-Vicencio, C., 1997, 'Telling one another stories: Toward a theology of reconciliation', in G. Baum \& H. Wells (eds.), The reconciliation of peoples, pp. 30-41, Orbis Books, New York.

Warner, R.S., 1996, 'Religion, boundaries and bridges', Sociology of Religion 58(3), 217-238. https://doi.org/10.2307/3712214

Widdershoven, G., 1997, 'The story of life: Hermeneutic perspectives on the relationship between narrative and life history', in R. Josselon \& A. Lieblich (eds.), The narrative study of lives, pp. 1-20, Sage, Newberry Park, CA.

Wielenga, C., 2013, 'Shattered stories: Healing and reconciliation in the South African context', Verbum et Ecclesia 34(1), Art. \#747, 1-8. https://doi.org/10.4102/ve. v34i1.747

Wuthnow, R., 1994, Sharing the journey: Support groups and America's new quest for community, Free Press, New York.

Yancey, G.A., 2003, One body, one spirit: Principles of successful multiracial churches, InterVarsity Press, Downers Grove, IL. 